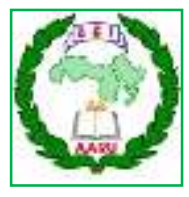

Arab Univ. J. Agric. Sci., Ain Shams Univ., Cairo, Egypt

29(1), 263 - 276, 2021

Website: http://ajs.journals.ekb.eg

DOI: 10.21608/ajs.2021.50000.1297

\title{
Natural Pigments Production by Local Bacterial Isolates for Use as Antibacterial and Antioxidant
}

\author{
Sohila G El-Sayed*, Mahmoud M Zaki, El-Sayed A Saleh, \\ Khadiga A Abou-Taleb \\ Agricultural Microbiology Dept, Faculty of Agriculture, Ain Shams University, P.O. \\ Box 68, Hadayek Shubra 11241, Cairo, Egypt \\ *Corresponding author: sohilagamal168@gmail.com
}

Received 5 December, 2020

Accepted 8 March, 2021

\begin{abstract}
Among 46 local bacterial isolates capable synthetized pigments, $26 \%$ produced extracellular of blue green and fluorescent whereas $74 \%$ produced intra-cellular pigments of red, brown, yellow, orange, and rose. Seven isolates were selected as a potential candidate for the synthesis of pigments. They were Pseudomonas fluoresces, $P$. aeruginosa, Serratia marcescens, Azotobacter chroococcum, Micrococcus kristinae, M. luteus, and M. roseus after their morphological and biochemical studies. They capable to produce fluorescent, blue green, red, brown, orange, yellow, and rose with maximum absorbance at 400, 520, $530,320,440,460$, and $470 \mathrm{~nm}$, with an optical density of $0.62,1.42,1.35,1.11,0.45,0.98$, and 0.40 , respectively. Antibacterial activity of pigments was studied against 7 bacterial pathogenic strains namely $P$. aeruginosa ATCC27853, Escherichia coli $0157 \mathrm{~h} 7$ ATCC25922, Klebsiella pneumoniae ATCC00607, Salmonella typhimurium ATCC25566, Listeria monocytogenes ATCC19115, Staphylococcus aureus ATCC29737, and Bacillus cereus ATCC33018. The last tested strain behaved high significant $(\mathrm{p} \leq 0.05)$ sensitivity for blue green, fluorescent, brown, and rose pigments while, L. monocytogenes ATCC19115 was more susceptible for red, and yellow pigments
\end{abstract}

and S. aureus ATCC29737 had more inhibited by orange pigment. These bacterial pigments seemed to have antioxidant activity which inhibited the formation of diphenyl-2-picrylhydrazyl radicals with percentage ranged from 40 $\%$ to $80 \%$. It could therefore be stated that the bacterial pigments tested had a broad impact on foodborne pathogens and had an antioxidant effect.

Keywords: Antibacterial agent; Bacterial pigments; Diphenyl-2-picrylhydrazyl scavenging activity.

\section{Introduction}

The word pigment originated in Latin and initially referred to a coloured substance but was later extended to mean coloured objects such as cosmetics. The word was also used at the beginning of the Middle Ages to describe various plant and vegetable extracts, particularly those used as food colourants (Ullmann 1985). Pigments are chemical compounds from the visual region that absorb light. The colour generated is due to the chromophore, a molecular structure that absorbs the sun's energy and causes electron excitation from the outer orbital to the upper orbital, where the non-absorbed energy is refracted or reflected such that the eye can catch it (Cristea and Vilarem 2006). Many pigmented compounds 
contain either $\mathrm{N}$ or $\mathrm{O}$, all of which are mostly comparatively large molecular weight molecules (Mw) of 200 (anthraquinones), 300 (anthocyanidins), 400 (betalaine), 500 (carotenoids) and 800 for chlorophylls (Hendry and Houghton 1996). Biological pigments can be divided into six main structural groups, including tetrapyrroles, tetraterpenoids, quinines, $\mathrm{O}$ heterocyclics, N-heterocyclics and metalloproteins.

Pigments are extracted from biological materials such as plants, animals, and microbes as a source of natural pigments. These natural colours are usually derived from fruits, vegetables, seeds, roots, and microorganisms and are also referred to as bio-colours owing to their biological origin. Benefits of natural pigments include health and safety aspects of natural colouring: while all natural colours are not $100 \%$ healthy, they are less harmful than their synthetic counterparts. Many natural colouring agents, such as turmeric, annatto and saffron, are allowed as food additives. Several natural colourants have pharmacological effects and potential health benefits. Natural pigments are cost effective and made from sustainable materials. There are no issues with recycling since they are biodegradable. Almost no or moderate reactions are involved in their preparation. They are unsophisticated and are in accordance with nature. A wide spectrum of colours can be achieved using separate mordants (Gürses et al 2016). A wide variety of pigments such as carotenoids, melanin, violacein, prodigiosin, pyocyanin, actinorhodin, and zeaxanthin are produced by fungi, algae, actinomycetes, and bacteria (Ahmad et al 2012; Venil et al 2014). Among the microbial pigment-producing organisms, bacteria provide some advantages based on their versatility, quick life cycle and easy propagation techniques. Examples of bacterial pigment-producing species include Flavobacterium sp. which produces yellow pigment zeaxanthin, Agrobacterium auranticum (pink-red pigment, astaxanthin), Micrococcus sp. and Serratia marcescens (red pigment), Micrococcus sp. and Xanthomonas sp. (yellow pigment) Planococcus maritime (orange pigment, carotenoids) and Chromobacterium sp. (violet pigment) have been reported by Chaudhari and Jobanputra (2013); Selvi and Iyer (2018) and Joshi et al (2019).

It has been observed that microbial pigments have an antimicrobial activity on some food pathogens and microorganisms that spoil food. Both Gram-positive and Gram-negative bacteria and fungi are prevented by microbial pigments (Türkkan 2007). Pigments such as Pseudomonas aeruginosa pyocyanine and pyorubin have shown significant antibacterial property against Citrobacter sp., which is usually associated with urinary tract and wound infections. (Narsing Rao et al 2017). The pigment had a high antioxidant potential and defended the bacteria against oxidative damage. Microbial pigments used as antioxidants may inhibit the development of some illnesses, such as cancer and heart failure (Correa-Llantén et al 2012; Manimala and Murugesan 2014; Arivizhivendhan et al 2018).

The goal of the current study was to obtain extra- and intra-cellular pigments synthesizing bacterial isolates and to assess bacterial pigments as antibacterial and antioxidant agents.

\section{Materials and Methods}

\subsection{Sample collection}

Various samples collected from various sources of soil (from El-Sharqia and ElQalyubia governorates), food (pickle water, luncheon, whey and yoghurt) obtained from the local market, and air collected from the Agricultural Microbiology Laboratory, Faculty of Agriculture, Ain Shams University, Cairo, Egypt. These samples were collected in sterile plastic bottles and placed in an ice box all the time they were delivered to the laboratory and kept at $4{ }^{\circ} \mathrm{C}$ until they were used. 


\subsection{Media used}

Glucose agar and broth media were used for isolation and preservation of the bacterial cultures and were prepared according to DIFCO (1984). They consist (g/L) of; 10, glucose; 5 , peptone; 3 , beef extract; 15 , agar, and the $\mathrm{pH}$ was adjusted to 7 .

King's B medium (King et al 1954) was used for isolation and phenotypic identification of Pseudomonas spp. It was composed $(\mathrm{g} / \mathrm{L})$ of 20 , proteose peptone; $1.5, \mathrm{~K}_{2} \mathrm{HPO}_{4}$; $1.5, \mathrm{MgSO}_{4} .7 \mathrm{H}_{2} 0 ; 10 \mathrm{ml}$, glycerol; 15 , agar, and then the $\mathrm{pH}$ was adjusted to 7.2.

Ashbys mannitol agar (Subba Rao 1977) was used for isolation and phenotypic identification of Azotobacter sp. It was composed $(\mathrm{g} / \mathrm{L})$ of 20 , mannitol; 0.2, $\mathrm{K}_{2} \mathrm{HPO}_{4} ; 0.2$, $\mathrm{MgSO}_{4} ; 0.2, \mathrm{NaCl} ; 0.1, \mathrm{~K}_{2} \mathrm{SO}_{4} ; 5, \mathrm{CaCo}_{3} ; 15$, agar and final $\mathrm{pH}$ was $7.4 \pm 0.2$ (at $25^{\circ} \mathrm{C}$ ).

MacConkey agar medium (OXOID CM0115) used in the cultivation of pathogenic bacteria of Escherichia coli $0157 \mathrm{~h} 7$ ATCC25922, Klebsiella pneumoniae ATCC00607, and Salmonella typhimurium ATCC25566. The weight of the medium powder $(51.5 \mathrm{~g})$ was suspended in $1000 \mathrm{ml}$ of distilled water and boiled for full dissolving. The medium was then dispensed in flasks and sterilized at $121^{\circ} \mathrm{C}$ by autoclaving for $15 \mathrm{~min}$.

Nutrient agar medium (DIFCO 1984) used for cultivation of other tested pathogenic bacteria.

\subsection{Pathogenic bacterial strains}

Seven strains namely, Pseudomonas aeruginosa ATCC27853, Escherichia coli 0157h7 ATCC25922, Klebsiella pneumoniae ATCC00607, Salmonella typhimurium ATCC25566, Listeria monocytogenes ATCC19115, Staphylococcus aureus ATCC29737, and Bacillus cereus ATCC33018 were collected from the Agric. Microbiol. Lab., Fac. of Agric., Ain Shams Univ., Cairo, Egypt.
2.4 Isolation, purification and maintenance of pigments producing bacteria

The collected samples were used to isolate bacteria producing pigments using glucose agar media and King's B medium according to the serial plate procedure, $10 \mathrm{~g}$ either food or soil (luncheon and yoghurt), and $10 \mathrm{ml}$ of liquid samples (pickle and whey) were suspended individually in $90 \mathrm{ml}$ sterilized water, mixed well for $10 \mathrm{~min}$ to obtain serial dilutions from $10^{-1}$ to $10^{-8}$. These suspensions, $1 \mathrm{ml}$ of these diluted suspensions were spread on glucose agar medium and King's B medium then incubated for $48 \mathrm{~h}$ (Sinha et al 2017). The purified cultures of pigment producing bacterial isolates were maintained on slants of glucose agar medium at $4^{\circ} \mathrm{C}$ in refrigerator until used.

\subsection{Identification of the most efficient bac- terial isolates}

The most efficient bacterial isolates in intra-cellular and extracellular pigments production were completely identified up to species based on their morphological, cultural, and physiological features based to the keys proposed by Holt et al (1994).

\subsection{Batch fermentation process}

The fermentation process was performed out in plugged Erlenmeyer flasks $(250 \mathrm{ml})$, each including medium glucose broth $(100 \mathrm{ml})$ and inoculated with an inoculum size of $4 \%$ $\left(10^{8}\right.$ colony forming unit (CFU) $/ \mathrm{ml}$ standard inoculum) for the tested bacterial isolates and were incubated at $37^{\circ} \mathrm{C}$ for $48 \mathrm{~h}$ in a rotary shaker $(150 \mathrm{rpm})$. The fermented medium was separated by centrifugation at $6000 \mathrm{rpm}$ for 15 min and the supernatant was used for the assessment of extracellular pigment and pellets for the assessment of intra-cellular pigments as shown below. 


\subsection{Intra-cellular pigment extraction and determination}

Cells (pellets) were obtained from fermented medium by centrifugation at $6000 \mathrm{rpm}$ for 15 minutes and washed 3 times with distilled water and then re-suspended in ethyl acetate solvent. The mixture was vortexed, then the suspension was centrifuged at $6000 \mathrm{rpm}$ for 10 minutes and the supernatant was collected. Absorption of the derived pigments was measured by UV-visible spectrophotometer (UnicoUV 2100) (Pore et al 2016).

\subsection{UV-Visible Spectrophotometer}

Synthesized pigments (supernatant containing extracellular or intra-cellular derived from pellets) were measured by UV-Vis spectral (Unico-UV 2100) at a wavelength of 300$700 \mathrm{~nm}$ (Sinha et al 2017) against distilled water or ethyl acetate solvent as blank for extraor intra-cellular pigments, respectively. Thus, the absorption maxima have been measured.

\subsection{Antibacterial activity}

The antibacterial efficacy of the pigments was evaluated against seven bacterial pathogens (P. aeruginosa, E. coli, K. pneumoniae, $S$. typhimurium, L. monocytogenes, $S$. aureus and B. cereus) as recommended by Waghela and Khan (2018) and express as diameter of inhibition zone using well diffusion agar.

\subsection{Antioxidant activity}

The antioxidant potential of the extracted pigment was assessed by the diphenyl-2-picrylhydrazile (DPPH) scavenging activity technique as mentioned by Devyani et al (2017). Two hundred microliters of pigment extract were mixed with $2 \mathrm{ml} \mathrm{DPPH}(0.02 \%)$ and incubated in a dark position for 30 minutes. Absorption was estimated at $517 \mathrm{~nm}$ by spectrophotometer (Unico-UV 2100), methanol was used as a blank and controls were also retained. The potential to scavenge DPPH radicals was calculated using the following equation:
DPPH scavenging impact $(\%)=A_{0}-A_{1} / A_{0}$ $\times 100$.

Where, $\mathrm{A}_{0}$ : absorbance of the control reaction and $A_{1}$ : absorbance of the sample.

\subsection{Data statistical analysis}

Data were statistically analyzed using IBM ${ }^{\circ}$ SPSS $®$ Statistics software (2017) according to Duncan's, (1955) at 5\% level.

\section{Results and discussion}

\subsection{Isolation of pigments producing bacte- rial isolates}

The distribution number and percentage of total bacteria produced pigments collected from different sources have been shown in Fig (1). A up to a total of 46 bacterial isolates were collected and the widely distributed number of isolates were 23 isolates collected from soil, 5 isolates isolated from air, and 18 isolates $(3,7$, 3 , and 5 isolates) obtained from food (pickle water, luncheon, whey and yoghurt), respectively. Whereas the percentage distribution of isolates was 50,11, and $39 \%$ represented in samples collected from soil, air and food, respectively (Fig 1). Bacteria forming pigments were common and available in numerous biological areas, like as soil, rhizospheric soil, desert sand, fresh water, and aquatic samples (Franks et al 2005; Peix et al 2005 Zhu et al 2007; Asker et al 2008; Liu et al 2009).

Among 46 local bacterial isolates capable synthetized pigments, $26 \%$ produced extracellular of blue green and fluorescent whereas 94\% produced intra-cellular pigments of red, brown, yellow, orange, and rose (Tables 1 and 2).

\subsection{Production of pigments by bacterial iso- lates}

This experiment was performed to find the most effective pigment-producing isolates. The data seen in Figs $\mathbf{2}$ and $\mathbf{3}$ clearly showed 
that the extra-and intra-cellular pigment density produced by bacterial isolates was expressed as OD. In Fig 2, the extracellular pigment intensity of both fluorescence and bluegreen pigments displayed optimum absorbance with a spectrophotometer at wavelengths of $400 \mathrm{~nm}$ and $520 \mathrm{~nm}$ respectively.

The highest significant $(p \leq 0.05)$ fluorescence and blue green pigment (OD) values were noted by SF2 and SG1 isolates being 0.62 and 1.42 , respectively. Whereas SF1 and SG6 isolates were reported for the minimum production of fluorescence $(0.46)$ and blue green (0.41) pigments, respectively.

Also, in case of intra-cellular pigments, the maximum absorption of the red, brown, orange, yellow, and rose colours was recorded at $530 \mathrm{~nm}, 250 \mathrm{~nm}, 460 \mathrm{~nm}$, and $470 \mathrm{~nm}$, respectively.

Data in Fig 3 indicated that the maximum significant density (OD) of red, brown, orange, yellow, and rose colours produced by isolates LRe6, SB1, AO2, WY12, and WRo5 were $1.35,1.11,0.45,0.98$, and 0.40 , respectively. Whereas the lowest pigments density values of red (0.05), brown (0.68), orange (0.24), yellow (0.13), and rose (0.17) were obtained by YRe7, SB3, LO3, LY9, and ARo3, respectively.

In addition, it could be stated that the most effective isolates SF2, SG1, LRe6, SB1, AO2, WY12 and WRo5 for different pigment production were selected for sequential studies.

\subsection{Determine the phenotype of the most ef- ficient bacterial isolates producing pig- ments}

The most efficient pigment producing isolates were completely identified up to species according to phenotypic (cultural, morphology, and physicochemical) characteristics according to the keys proposed by Holt et al 1994. Both isolates produced blue green and fluorescent pigments are belonging to the genus Pseudomonas. For identification of pseudomonas isolates (SG1) and (SF2) their morphological and physiological characteristics were studied Data showed that their characterized as short rods, Gram negative, motile, starch hydrolyses negative, lipase positive, gelatin liquefaction positive, and produced blue green pigment at $30^{\circ} \mathrm{C}$, and fluorescent pigment at $5^{\circ} \mathrm{C}$. Therefore the experimental isolates (SG1) and (SF2) were identified as pseudomonas aeruginosa and pseudomonas fluorescence, respectively.

The brown pigment producing isolate (SB1) was completely classified as Azotobacter chroococcum which appeared as coccoid, cells are usually single but may occur in pairs, Gram negative, motile, aerobic, produced water-soluble pigment, and peroxidase.

The red pigment producing isolate (LRe6) was completely classified as Serratia marcescens which appeared as rod-shaped, Gramnegative bacteria, facultative anaerobe, motile, grow in temperatures ranging from $5-40^{\circ} \mathrm{C}$, and in $\mathrm{pH}$ levels ranging from 5 to 9 and presence of $\mathrm{NaCl} 0-4 \%$, catalase positive, and reduced nitrates.

The yellow pigment producing isolate (WY12) was classified as Micrococcus luteus which appeared as gram positive cocci, smooth colonies with regular edge, nonmotile, endospores are not formed, catalase and oxidase positive, growth on nutrient agar with $7.5 \%$ $\mathrm{NaCl}$, and growth on inorganic nitrogen agar.

The rose pigment producing isolate (WRo5) was classified as Micrococcus roseus which appeared as gram positive cocci, smooth colonies with regular edge, nonmotile, endospores are not formed, catalase and oxidase positive, produced acid from glucose, not growth on nutrient agar with $7.5 \% \mathrm{NaCl}$, and not growth on inorganic nitrogen agar.

The orange pigment producing isolate (AO2) was detected by Micrococcus kristinae which appeared as gram positive cocci, smooth colonies with regular edge, nonmotile, endospores are not formed, catalase and oxidase positive, produced acid from glucose, growth on nutrient agar with $7.5 \% \mathrm{NaCl}$, and not growth on inorganic nitrogen agar. 


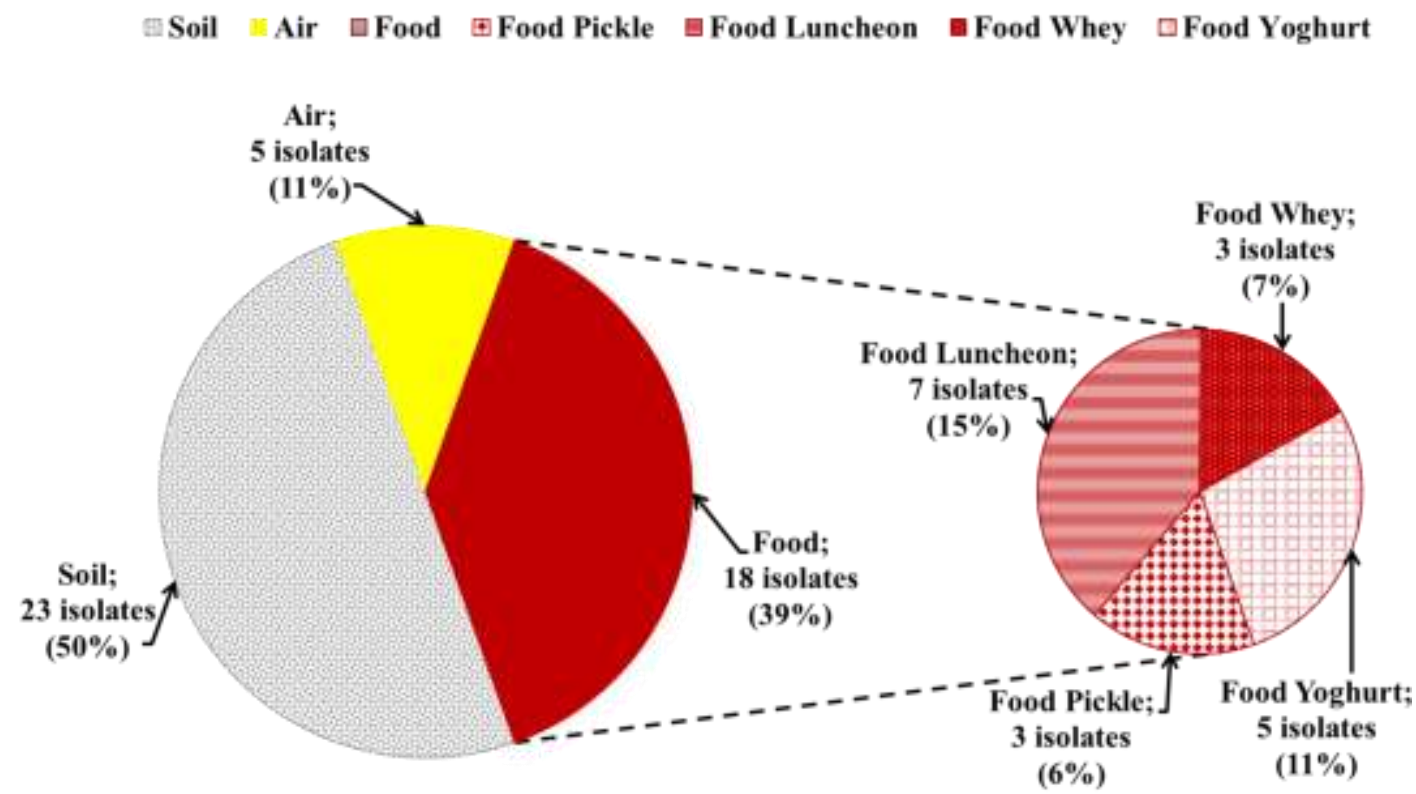

Number and percentage of isolates

Fig 1. Distribution percentage of pigments producing bacterial isolates collected from various sources

Table 1. Percentage number and morphological characters of bacterial isolates capable of producing extracellular pigments

\begin{tabular}{|l|c|c|c|c|c|c|}
\hline \multirow{2}{*}{ Pigments colour } & \multicolumn{2}{|c|}{ Bacterial isolates } & \multicolumn{3}{c|}{ Morphological characteristics } \\
\cline { 2 - 6 } & No. & Percentage (\%) & \multicolumn{2}{|c|}{ Gram stain } & \multicolumn{2}{c|}{ Shape } \\
\cline { 3 - 7 } & & & G+ $^{\text {ve }}$ & G $^{\text {-ve }}$ & Rod & Cocci \\
\hline Blue green & 10 & 22 & - & + & + & - \\
\hline Fluorescent & 2 & 4 & - & + & + & - \\
\hline
\end{tabular}

- $\quad$ No.= Number, $\mathrm{G}^{+\mathrm{ve}}=$ Gram positive, and $\mathrm{G}^{-\mathrm{ve}}=$ Gram negative.

Table 2. Percentage number and morphological characters of bacterial isolates capable of producing intracellular pigments

\begin{tabular}{|c|c|c|c|c|c|c|}
\hline \multirow[t]{3}{*}{ Pigments colour } & \multicolumn{2}{|c|}{ Bacterial isolates } & \multicolumn{4}{|c|}{ Morphological characteristics } \\
\hline & \multirow[t]{2}{*}{ No. } & \multirow{2}{*}{$\begin{array}{c}\text { Percentage } \\
(\%)\end{array}$} & \multicolumn{2}{|c|}{ Gram stain } & \multicolumn{2}{|c|}{ Shape } \\
\hline & & & G+ve & $G^{-v e}$ & Rod & Cocci \\
\hline Red & 7 & 15 & - & + & + & - \\
\hline Brown & 3 & 7 & - & + & - & + \\
\hline Yellow & 13 & 28 & + & - & - & + \\
\hline Rose & 8 & 17 & + & - & - & + \\
\hline Orange & 3 & 7 & + & - & - & + \\
\hline
\end{tabular}

- $\quad$ No. $=$ Number, $\mathrm{G}^{+\mathrm{ve}}=$ Gram positive, and $\mathrm{G}^{-\mathrm{ve}}=$ Gram negative . 


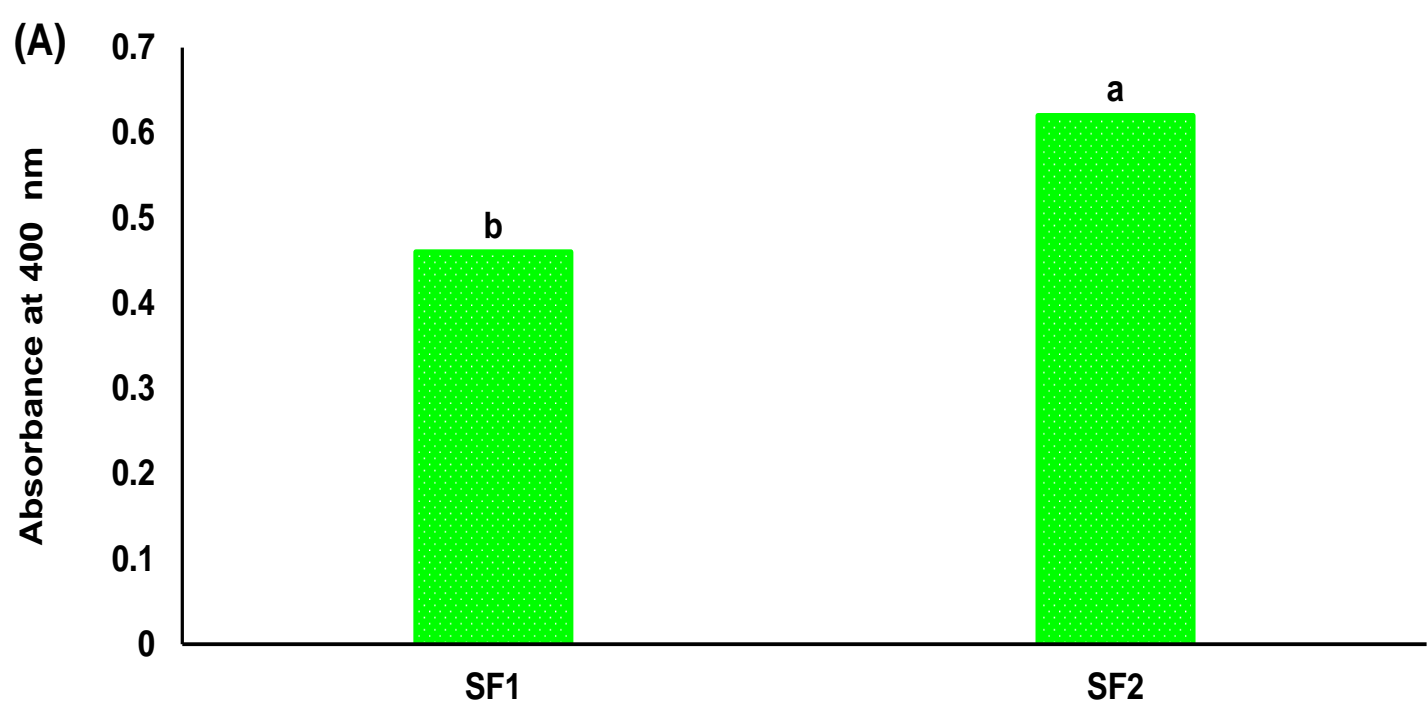

Fluorescence pigment producing isolates

(B)

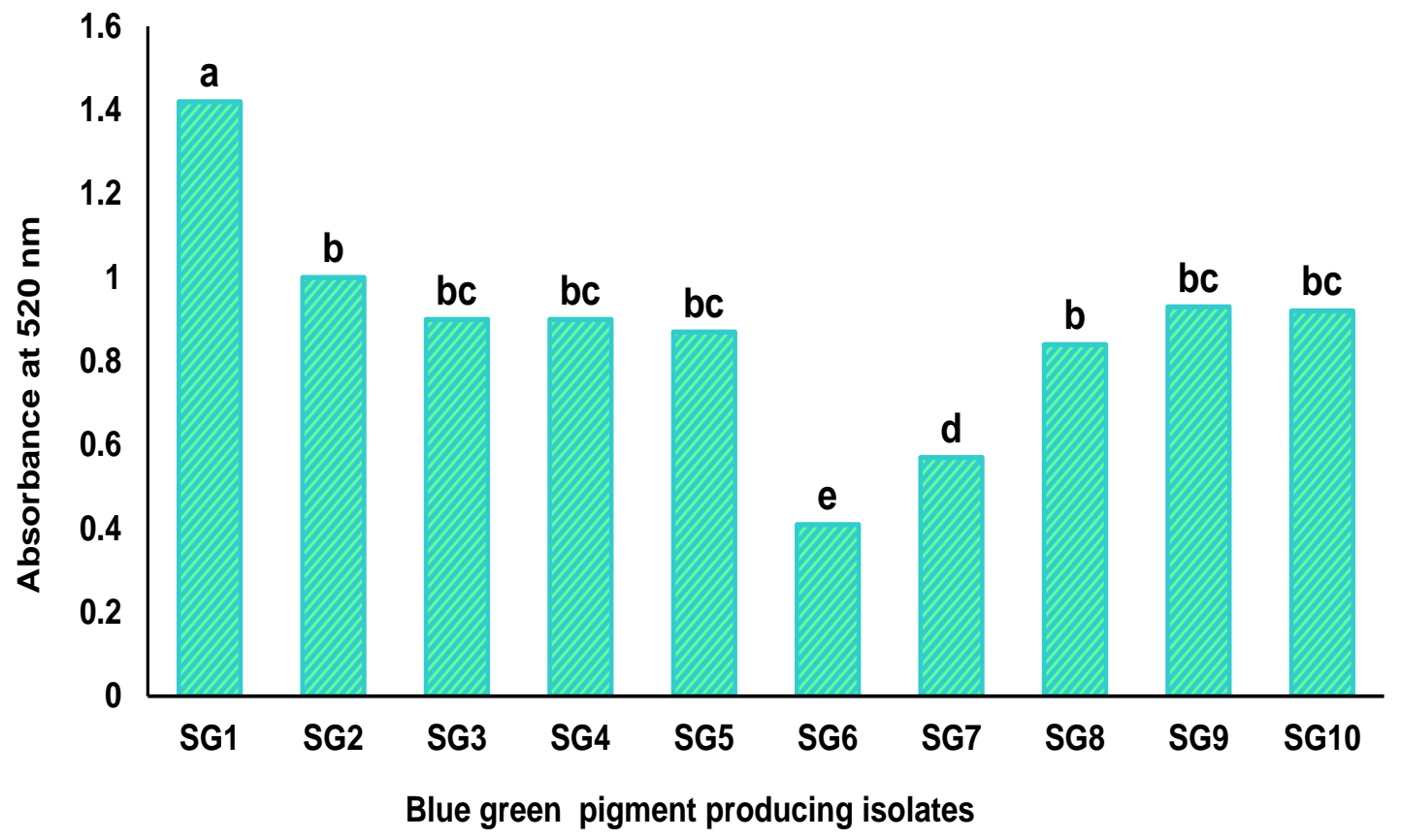

Fig 2. Extra-cellular pigments fluorescence (A), and blue green (B) production by bacterial isolates

- ${ }^{\mathrm{a}, \mathrm{b}}$ Values above columns followed by the different letters are significantly difference according to Duncan's $(p \leq 0,05)$. 

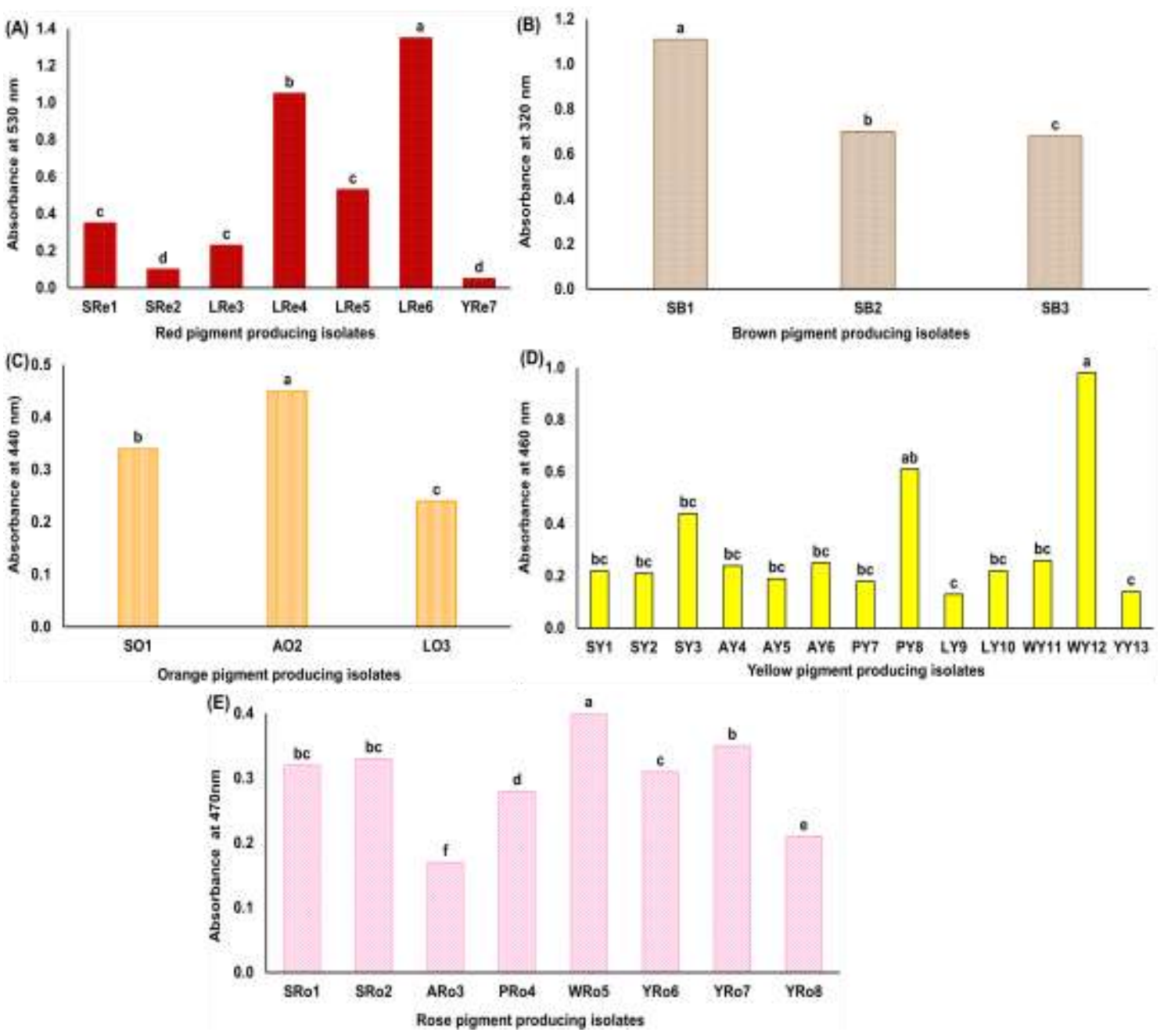

Fig 3. Intra-cellular pigments production by bacterial isolates. (A) Red colour, (B) Brown colour, (C) Orange colour, (D) Yellow colour, and (E) Rose colour

- a, b Values above columns followed by the different letters are significantly difference according to Duncan's $(\mathrm{p} \leq 0.05)$.

Prodigiosins, a class of natural red pigments identified by a specific skeleton of pyrrolylpyrromethane, are formed by different bacteria that were first described by $S$. marcescens (Khanafari et al 2006). In addition, Selvi and Iyer 2018 have identified natural colour pigments from bacteria, i.e. yellow (Xanthomonas sp.), orange (Sarcina sp.), and pinkred (Rhodotorula sp.).
3.4 Antibacterial activity of pigments extracted from bacterial isolates against some pathogenic bacteria

In the present investigation, the antibacterial activity of 7 pigments (blue green, fluorescent, red, brown, orange, rose and yellow) extracted from $P$. aeruginosa (SG1), $P$. fluoresces (SF2), S. marcescens (LRe6), A. chroococcum (SB1), M. kristinae (AO2), $M$. 
roseus(WRo5), and M. luteus (WY12) respectively were tested against pathogenic bacterial strains of Pseudomonas aeruginosa ATCC27853, Escherichia coli $0157 \mathrm{~h} 7$ ATCC25922, Klebsiella pneumoniae ATCC00607, Salmonella typhimurium ATCC25566, Listeria monocytogenes ATCC19115, Staphylococcus aureus ATCC29737, and Bacillus cereus ATCC33018. Data in Table 3 exhibited that both blue green and fluorescent extra-cellular pigment produced from $P$. aeruginosa (SG1), and $P$. fluoresces (SF2) inhibited the growth of all the tested pathogenic bacteria with spectrum activity of $100 \%$. Bacillus cereus ATCC 33018 was more significant $(p \leq 0.05)$ sensitivity to both blue green and fluorescent pigments which recorded 21 and $26 \mathrm{~mm}$ of inhibition zone diameter (IZD). The fluorescent pigment gave higher efficacy against pathogenic bacteria than blue green pigment. The Inhibition zone diameter ranged from 6 to $16 \mathrm{~mm}$ against the tested pathogenic bacteria (P. aeruginosa ATCC27853, E. coli $0157 \mathrm{~h} 7$ ATCC25922, K. pneumoniae ATCC00607, $S$. typhimurium ATCC25566, L. monocytogenes ATCC19115, Staph. aureusATCC29737 and B. cereus ATCC33018) Whereas the blue green pigment gave inhibition zone ranged from 5 to $6 \mathrm{~mm}$.

Results represented in Table 3 also indicated that all intra-cellular pigments were achieved $100 \%$ spectrum activity against all the tested pathogenic bacteria expect red and orange pigments were 85.7 and $42.9 \%$ of spectrum activity, respectively. Salmonella typhimurium ATCC25566 was resistant to red pigment extracted from $S$. marcescens, and four strains namely, K. pneumoniae ATCC00607, S. typhimurium ATCC25566, L. monocytogenes ATCC19115, and B. cereus ATCC33018 were resistant to orange pigment produced from $M$. kristinae. The antibacterial activity of red pigment toward L. monocytogenes ATCC19115 had more significant $(\mathrm{p} \leq$ 0.05 ) with IZD of $11 \mathrm{~mm}$. Brown pigment produced from A. chroococcum gave significant IZD for Staph. Aureus ATCC29737 and B. cereus ATCC 33018 being $23 \mathrm{~mm}$. Whereas the pigments produced from Micrococcus spp. show antibacterial activity; orange pigment achieved significant activity against E. coli $0157 \mathrm{~h} 7$ ATCC25922 being $21 \mathrm{~mm}$ of IZD. Rose pigment recorded high IZD against $K$. pneumoniae ATCC00607, and B. cereus ATCC33018 being $13 \mathrm{~mm}$. Yellow pigment registered large significant diameter zone against three strains of $S$. typhimurium ATCC25566, L. monocytogenes ATCC19115, and Staph. aureusATCC29737 being $11 \mathrm{~mm}$.

The M. luteus KF532949 pigments had shown positive antibacterial effect against relevant pathogens such as Staphylococcus sp., Klebsiella sp., and Pseudomonas sp. (Umadevi and Krishnaveni 2013). Prodigiosin had antibacterial activity at a concentration of $10 \mathrm{~g} / \mathrm{ml}$ against six chosen food-borne pathogenic strains, such as E. coli $(0.6 \mathrm{~cm})$, B. cereus $(0.6$ $\mathrm{cm})$, Staph. aureus $(0.6 \mathrm{~cm})$, C. botulinum $(0.7$ $\mathrm{cm}), V$. vulnificus $(0.2 \mathrm{~cm})$, and $S$. entertids $(0.5 \mathrm{~cm})$ have been reported by Arivizhivendhan et al (2018). Selvi and Iyer (2018) reported that the highest inhibition zone of the carotenoid pigments was $13.5 \mathrm{~mm}$ of against Staphylococcus sp. as well as $12.5 \mathrm{~mm}$ against E. coli. Koyyati et al (2019) indicated that bacterial pigments isolated from two novel strains of Rhodopseudomonas palustris showed effective antibacterial activity in contrast to ampicillin against gram-negative and gram-positive bacteria.

From above result, it could be observed that the different bacterial pigments had antibacterial activity toward some gram positive and negative bacteria.

\subsection{Antioxidant activity}

The antioxidant potential of bacterial synthesizing extra- and intra-cellular pigments was studied by estimating free radicals scavenging assay. Data in Fig 4 showed that the percentage inhibition of formation of Diphenyl-2-picrylhydrazyl radicals with the tested pigments was ranged from 40 to $80 \%$. The scavenging activities of DPPH exerted by both extra-cellular pigments of fluorescence, and blue green showed $60 \%$, and $70 \%$ inhibition. 
Whereas DPPH scavenging activities exerted by intra-cellular pigments of rose, orange, red, brown and yellow gave 40, 50, 65, 72, and 80 $\%$ inhibition, respectively. The yellow pigment extracted from M. luteus (WY12) was more significant scavenging activity of DPPH followed by both blue green and red pigments extracted from $P$. aeruginosa (SG1), and S. marcescens (LRe6). So, it could be stated that the tested bacterial pigments had antioxidant effect.

Pigments such as xanthomonad displayed antioxidant function and photo damage safety (Tuli et al 2015). At the 2, 4, 6, 8, and $10 \mathrm{~g} / \mathrm{ml}$ concentration of prodigiosin, the scavenging activity of prodigiosin was observed to be 25 , $51, \quad 74, \quad 92, \quad$ and $99 \%$, respectively (Arivizhivendhan et al 2018). In vitro antioxidant effectiveness of bacterial pigments (extracellular) and bacterial extracts (intra-cellular) has been assessed by DPPH assays. More radical scavenging behaviour was seen by the A2 and Rp KRPR02 pigments. The percent inhibition of DPPH radical for pigment A2 $(82.74 \pm 4.49)$ and bacterial extract of $\mathrm{Rp}$ KRPR02 bacteria $(83.33 \pm 5.46)$ is almost identical to the usual percentage inhibition of DPPH radical (ascorbic acid), which is 96.41 \pm 1.81 (Koyyati et al 2019).

Table 3. Impact of extra and intracellular bacterial pigments on pathogenic bacteria expressed as IZD and their spectrum activity

\begin{tabular}{|c|c|c|c|c|c|c|c|c|c|}
\hline \multirow{2}{*}{\multicolumn{2}{|c|}{ Pigments }} & \multicolumn{7}{|c|}{ IZD of Pathogenic Bacteria (mm) } & \multirow{2}{*}{$\begin{array}{c}\text { Spectrum activ- } \\
\text { ity (\%) }\end{array}$} \\
\hline & & 1 & 2 & 3 & 4 & 5 & 6 & 7 & \\
\hline \multirow{2}{*}{ 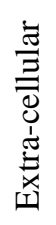 } & Blue green & $6^{\mathrm{b}}$ & $5^{\mathrm{b}}$ & $5^{\mathrm{b}}$ & $5^{\mathrm{b}}$ & $6^{\mathrm{b}}$ & $5^{\mathrm{b}}$ & $21^{\mathrm{a}}$ & 100 \\
\hline & Fluorescent & $6^{\mathrm{de}}$ & $6^{\mathrm{e}}$ & $9^{\text {cd }}$ & $11^{\mathrm{c}}$ & $16^{\mathrm{b}}$ & $6^{\mathrm{e}}$ & $26^{\mathrm{a}}$ & 100 \\
\hline \multirow{5}{*}{ 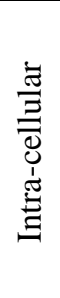 } & Red & $3^{c}$ & $6^{\mathrm{bc}}$ & $6^{\mathrm{bc}}$ & $-{ }^{\mathrm{d}}$ & $11^{\mathrm{a}}$ & $6^{\mathrm{b}}$ & $6^{\mathrm{bc}}$ & 85.7 \\
\hline & Brown & $8^{\mathrm{cd}}$ & $10^{c}$ & $13^{\mathrm{b}}$ & $6^{\mathrm{d}}$ & $13^{\mathrm{b}}$ & $23^{\mathrm{a}}$ & $23^{\mathrm{a}}$ & 100 \\
\hline & Orange & $3^{c}$ & $21^{\mathrm{a}}$ & $-\mathrm{d}$ & $-\mathrm{d}$ & $-\mathrm{d}$ & $13^{\mathrm{b}}$ & $-\mathrm{d}$ & 42.9 \\
\hline & Rose & $8^{\mathrm{b}}$ & $9^{\mathrm{b}}$ & $13^{\mathrm{a}}$ & $8^{\mathrm{b}}$ & $3^{c}$ & $6^{\mathrm{bc}}$ & $13^{\mathrm{a}}$ & 100 \\
\hline & Yellow & $3^{\mathrm{d}}$ & $3^{\mathrm{d}}$ & $5^{\mathrm{c}}$ & $11^{\mathrm{a}}$ & $11^{\mathrm{b}}$ & $11^{\mathrm{ab}}$ & $6^{c}$ & 100 \\
\hline
\end{tabular}

- $\mathrm{IZD}=$ Inhibition zone diameter, $\mathrm{mm}=$ milli meter.

- $\quad$ original zone diameter $=0.7 \mathrm{~mm}$

- 1- Pseudomonas aeruginosa ATCC27853, 2- Esherichia coli 0157h7 ATCC25922, 3- Klebsiella pneumoniae ATCC00607, 4- Salmonella typhimurium ATCC25566, 5- Listeria monocytogenes ATCC19115, 6- Staphylococcus aureus ATCC29737, and 7- Bacillus cereus ATCC33018. Spectrum activity = $\frac{\text { Number of sensitivity pathogenic }}{\text { Number of tested pathogenic isolates }} \times 100$.

- a,b Values with different superscripts within a row are significantly difference as described by Duncan's (1955) at $p \leq 0.05$. 


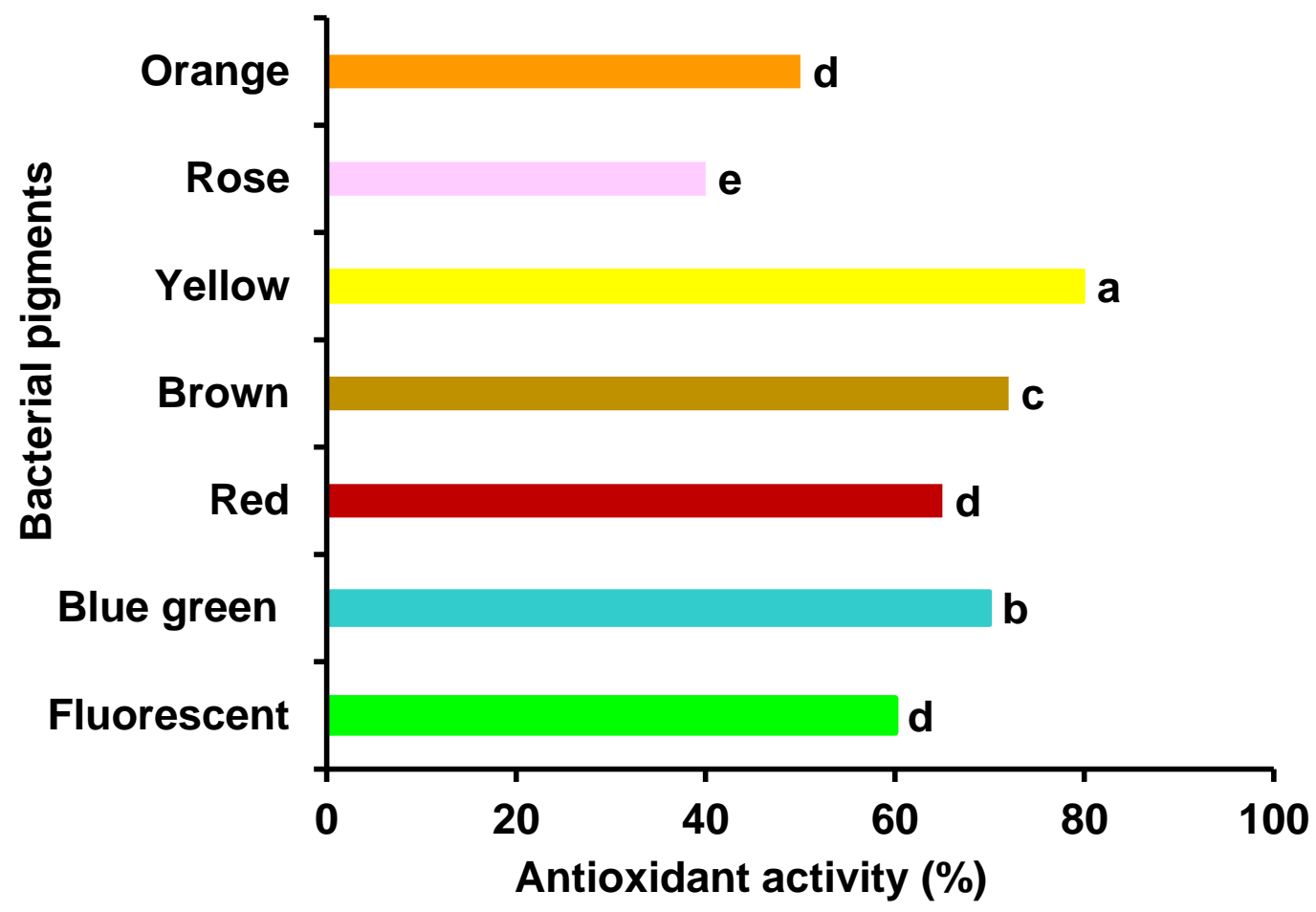

Fig. 4. The percentage inhibition of Diphenyl-2-picrylhydrazyl radical scavenging activity of pigments

- a, b Values above columns followed by the different letters are significantly difference according to Duncan's $(p \leq 0.05)$.

\section{Conclusions}

In this work, pigments are produced by 46 local bacterial isolates obtained from soil, air, and food. Twelve and thirty-six isolates produced extracellular and intracellular pigments, respectively. Of the 46 isolates, 7 isolates had a high production of pigments and were classified as $P$. fluorescence, $P$. aeruginosa, $S$. marcescens, A. chroococcum, M. kristinae, M. luteus, and M. roseus for the production of fluorescent, blue green, red, brown, orange, yellow, and rose colours, respectively. These pigments were extracted and used as a strong antibacterial agent against some gram positive and negative bacteria and as free radicals scavenging of DPPH.

\section{References}

Ahmad, WA; Ahmad, WYW; Zakaria, ZA; Yusof, NZ. (2012) Application of Bacterial Pigments as Colorant. Springer Briefs in Molecular Science, pp. 57-74.

Arivizhivendhan, KV; Mahesh, M; Boopathy, R; Swarnalatha, S; Regina Mary, R; Sekaran, G. (2018) Antioxidant and antimicrobial activity of bioactive prodigiosin produces from $\mathrm{Ser}$ ratia marcescens using agricultural waste as a substrate. J Food Sci Technol, 55, 2661-2670.

Asker, D; Beppu, T; Ueda, K. (2008) Nubsella zeaxanthinifaciens gen. nov., sp. nov., a zeaxanthin-producing bacterium of the family Sphingobacteriaceae isolated from freshwater. Int J Syst Evol Microbiol., 58, 601-606. 
Chaudhari, VM; Jobanputra, AH. (2013) Isolation, identification and characterization of novel pigment producing bacteria from distillery spent wash, Indian J Biotechnol, 7, 194200

Correa-Llantén, DN; Amenábar, MJ; Blamey, JM (2012) Antioxidant capacity of novel pigments from an Antarctic bacterium. J Microbiol, 50, 374-379.

Cristea, D; Vilarem, G. (2006) Improving light fastness of natural dyes on cotton yarn, Dyes and Pigments, 70, 238-245.

Devyani, M; Shraddha, $R$; Bela, N (2017) Isolation and screening of antioxidant bacterial pigments from different ecological niche. Int Res J of Science \& Engineering, 5, 119-125.

DIFCO. (1984) Dehydrated culture Media and reagents for Microbiology. $10^{\text {th }} \mathrm{Ed}$. Difco Laboratories, Detroit, M. (ed.) U.S.A.

Duncan, DB (1955) Multiple range and multiple F test. Biometrics, 11, 1-42.

Franks, A; Haywood, P; Holmstrom, C; Egan, S; Kjelleberg, S; Kumar, N (2005) Isolation and structure elucidation of a novel yellow pigment from the marine bacterium Pseudoalteromonas tunicate. Molecules, 10, 1286-1291.

Gürses, A; Açıkyıldız, M; Güneş, K; Gürses, MS (2016) Dyes and Pigments, Springer, pp. 69-80.

Hendry, GAF; Houghton, JD (1996) Natural food colorants, $2^{\text {nd }}$ edn. Blackies Academic \& Professional: imprint of Champan \& Hall, Great Britain, pp. 40-79.

Holt, JG; Krieg, NR; Sneath, PHA; Staley, JT; Williams, ST (1994) In: Bergey 's Manual of Determinative Bacteriology $9^{\text {th }}$ ed, Group 4: Gram negative aerobic / microaerophilic rods and cocci, 77-153, Group 5: Facultatively anaerobic gram negative rods, 187-218, Group 17: Gram positive cocci, 530-542, Williams and Wilkins Press, Baltimore, USA.
Joshi, PP; Yewatkar, KS; Ghumare, RR; Aglave, DT 2019. Isolation, Characterization of Yellow Pigments Producing Bacteria. EC Clinical and Experimental Anatomy, 2, 316322.

Khanafari, A; Assadi, MM; Fakhr, FA 2006. Review of Prodigiosin, Pigmentation in Serratia marcescens. Online J Biol Sci, 6, 1-13.

King, EO; Ward, MK; Raney, DE (1954) Two simple media for the demonstration of pyocyanin and fluorescein. J Lab Clin Med, 44, 301307.

Koyyati, R; Kudle, KR; Padigya, PRM (2019) Antibacterial, antioxidant and cytotoxic activity of bacterial carotenoids isolated from Rhodopseudomonas palustris KRPR01 and KRPR02. Int J Pharm Sci \& Res, 10, 4644-49.

Liu, M; Peng, F.; Wang, Y; Zhang, K; Chen, G; Fang, C (2009) Kineococcus xinjiangensis sp. nov., isolated from desert sand. Int J Syst Evol Microbiol, 59, 1090-1093.

Manimala, M; Murugesan, R (2014) In vitro antioxidant and antimicrobial activity of carotenoid pigment extracted from Sporobolomyces $\mathrm{sp}$. isolated from natural source. Journal of Applied and Natural Science, 6, 649-653.

Narsing Rao, MP; Xiao, M; Li, WJ 2017. Fungal and Bacterial Pigments: Secondary Metabolites with Wide Applications. Front Microbiol, 8, 1113.

Peix, A; Berge, O; Rivas, R; Abril, A; Velazquez, E (2005) Pseudomonas argentinensis sp. nov., a novel yellow pigment-producing bacterial species, isolated from rhizospheric soil in Cordoba, Argentina. Int J Syst Evol Microbiol, 55, 1107-1112.

Pore, TS; Khanolkar, AB; Nadaf, NH (2016) Production, purification, identification of prodigiosin from Serratia sp. and its antimicrobial activity. Res J Life Sci, Bioinform. Pharmaceut Chem Sci, 1, 326-337. 
Selvi, PS; Iyer, P 2018. Isolation and Characterization of Pigments from Marine Soil Microorganisms. Int J Life Sci Scienti Res, 4, 2003-2011.

Sinha, S; Choubey, S; Ajay Kumar, A; Bhosale, P (2017) Identification, Characterization of pigment producing bacteria from Soil and Water and Testing of Antimicrobial Activity of Bacterial Pigments. Int J Pharm Sci Rev Res, 42, 119-124.

Subba Rao (1977) Soil Microorganisms and Plant Growth, Oxford and IBH Publishing Co., India

Tuli, HS; Chaudhary, P; Beniwal, V; Sharma, AK (2015) Microbial pigments as natural color sources: current trends and future perspectives. J Food Sci Technol, 52, 4669-4678.

Türkkan, E (2007) Antibacterial effects against some pathogen food-borne bacteria of carotenoids extracted from Rhodotorula glutinis. MSc Thesis, Department of Food Engineering Institute of Natural and Applied Science University of Çukurova, Adana, Turkey.
Ullmann, F (1985) Ullmann Encyclopedia of Industrial Chemistry, $2^{\text {nd }} e d$, Edit, VCH Weinheim, $584 \mathrm{p}$.

Umadevi, K; Krishnaveni, M (2013) Antibacterial activity of pigment produced from $\mathrm{Mi}$ crococcus luteus KF532949. Int J Chem Anal Sci, 4, 149-152.

Venil, CK; Aruldass, CA; Dufosse, L; Zakaria, ZA; Ahmad, WA (2014) Current perspective on bacterial pigments: emerging sustainable compounds with coloring and biological properties for the industry-an incisive evaluation. RSC Adv., 4, 39523-39529.

Waghela, M; Khan, S (2018) Isolation, Characterization of Pigment Producing Bacteria from various food samples and testing of antimicrobial activity of bacterial Pigments. DAV International Journal of Science, 7, 1-8.

Zhu, HH; Guo, J; Yao, Q; Yang, SZ; Deng, MR; Phuong le, TB; Hanh, VT; Ryan, MJ (2007) Streptomyces vietnamensis sp. nov., a streptomycete with violet blue diffusible pigment isolated from soil in Vietnam. Int J Syst Evol, Microbiol, 57, 1770-1774. 


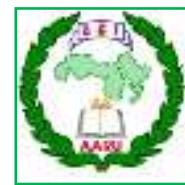

مجلة اتحاد الجامعات العربية للعلوم الزراعية، جامعة عين شمس، القاهرة، مصر

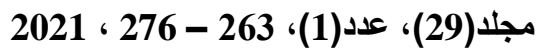

Website: http://ajs.journals.ekb.eg

DOI: 10.21608/ajs.2021.50000.1297

\title{
إنتاج أصباغ طبيعية من العزلات البكتيرية المحلية لاستخدامها \\ كمضاد للبكتيريا ومضاد للأكسدة
}

\author{
سهيلة جمال السيد" - محمود محمد زكي - السيد أحمد صالح - خليجة أحمد أبوطالب \\ قسم الميكروبيولوجية الزراعية- كلية الزراعة - جامعة عين شمس - ص.ب. 68 - حدائق شبرا 11241 - القاهرة - مصر حمر
}

*Corresponding author: sohilagamal168@gmail.com

Received 5 December, 2020

Accepted 8 March, 2021

\begin{tabular}{|c|c|}
\hline $\begin{array}{ll}\text { Escherichia } & \text { ،aeruginosa ATCC27853 } \\
\text { Klebsiella } & \text { ،coli 0157h7 ATCC25922 }\end{array}$ & \\
\hline almonella ، pneumoniae ATCC00607 & من بين 46 عزلة بكتيرية محلية قادرة على انتاج \\
\hline ،typhimurium & صبغات مخلقة، 26\% أنتجت صبغات خارجية من \\
\hline monocytoge & اللون الأخضر المزرق والفلوريسنت بينما 74\% أنتجت \\
\hline Staphylococcus aureus & صبغات داخلية من اللون الأحمر والبني والأصفر \\
\hline وأظهرت اخر سلالة اعلى معنوية (0.05 & والبرتقالي والوردى. وقد تم اختيار سبع عزلات محتملة \\
\hline لحساسيتها للصبغات الخضراء المزرقة والفلوريسنتية & Pseudomonas هرشحة لتخليق الصبغات. هم \\
\hline بينما كانت السلالة & Serratia ‘ $P$. aeruginosa ، fluoresces \\
\hline monocytogenes ATCC19115 أكثر حساس & ‘Azotobacter chroococcum ‘marcescens \\
\hline الحمراء والصفراء و كانت الصبغة البرتقال & M. و M. luteus ،Micrococcus kristinae \\
\hline reus ATCC29737 لسلالةre & roseus بعد دراسة الشكل المورفولوجى والخصائص \\
\hline عبغات البكتيرية محل & الكميائية. لهم القدرة على انتاج الصبغات الفلوريسنت \\
\hline ل لها نشاط مضد & والخضراء المزرا \\
\hline 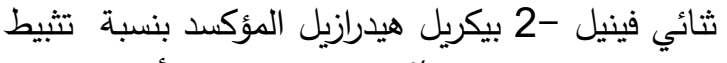 & 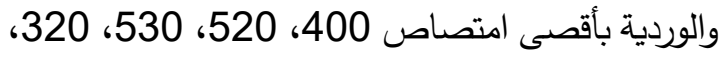 \\
\hline 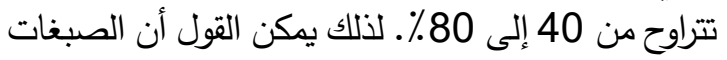 & 440، 460 و و470 نانومتر \\
\hline واسع على مسببات & 1.3، 1.11، 0.45، 0.98، 0.40، على \\
\hline 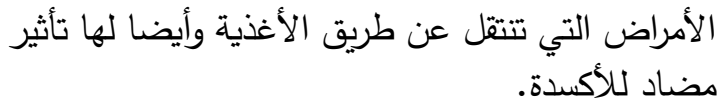 & سة الصبغات كنشاط مضاد للبكتيريا \\
\hline
\end{tabular}

